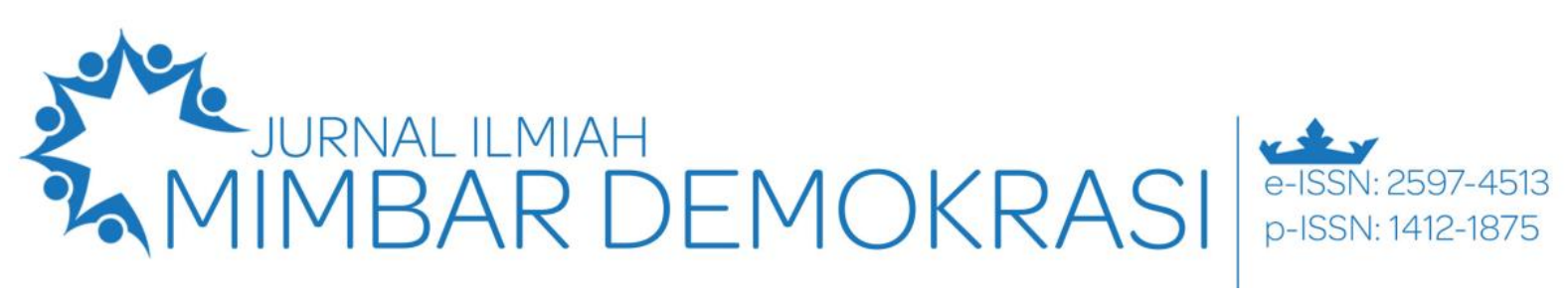

Vol. 20 No. 2 Tahun $2021 \mid$ Hal. $81-88$

\title{
Penerapan Kompetensi Kewarganegaraan dalam Upaya Konservasi Ekosistem Laut Melalui Keterlibatan Maumere Diver Community
}

Ludovikus Bomans Wadu ${ }^{a, 1 *}$, Andri Fransiskus Gultom a,2, Maria Regina Wesa Wunu a,3

a Universitas Kanjuruhan Malang, Indonesia

${ }^{1}$ ludovikusbomanwadu@unikama.ac.id*

*korespondensi penulis

Informasi artikel
Diterima:
11-10-2020
Disetujui:
16-04-2021
Kata kunci:
Pendidikan
Kewarganegaraan,
Keterlibatan Warga
Negara, Maumere
Diver Community,
Konservasi Laut,
Pembangunan
Berkelanjutan.

Received:

11-10-2020

Accepted:

16-04-2021

\section{Keywords:}

Citizenship Education,

Citizen Engagement,

Maumere Diver

Community,

Marine Conservation,

Sustainable Development.

\begin{abstract}
ABSTRAK
Pendidikan Kewarganegaraan (PKn) adalah suatu mata pelajaran wajib yang diterapkan di setiap jenjang Pendidikan di Indonesia agar dapat mengarahkan peserta didik untuk menjadikan pribadi yang berintelektual maupun berakhlak mulia sesuai dengan asas bangsa Indonesia. Untuk mencapai misi tersebut maka dibutuhkan kompetensi kewarganegaraan. Penelitian ini bertujuan untuk menjelaskan penerapan PKn melalui Maumere Diver Community. Metode penelitian ini adalah kualitatif dengan pendekatan studi kasus. Teknik pengumpulan data menggunakan observasi, wawancara, dan dokumentasi yang termasuk dalam teknik triangulasi. Berdasarkan hasil analisis data yakni reduksi, penyajian data, serta menarik kesimpulan bahwa penerapan PKn yang dilakukan memuat tiga kompetensi kewarganegaraan yakni kompetensi pengetahuan, sikap, dan keterampilan. Pada kompetensi pengetahuan warga negara diberi suatu edukasi tentang alam laut serta pengaruhnya bagi kehidupan mahkluk hidup serta pelatihan diving. Maumere Diver Community menerapkan kompetensi sikap adalah dengan cara menjadi teladan bagi warga negara untuk menanamkan sikap peduli terhadap lingkungan laut serta kelestariannya. Sedangkan pada kompetensi keterampilan, Maumere Diver Community berkolaborasi dengan komunitas Trash Hero dalam pengolahan sampah agar menambah nilai jual.
\end{abstract}

\begin{abstract}
The Citizenship Competency Implementation in Marine Ecosystem Conservation Through The Involvement of Maumere Diver Community. Citizenship Education (PKn) is a compulsory subject that is applied at every level of education in Indonesia in order to make an intellectual and noble person in accordance with the principles of the Indonesian nation. To achieve this mission, citizenship competency is required. This study aims to explain the application of PKn through Maumere Diver Community. This research method is qualitative with case study approach. Data collection techniques using observations, interviews, and documentation are included in triangulation techniques. Based on the results of data analysis, namely reduction, presentation of data, and drawing conclusions that the application of PKn carried out contains three competencies of citizenship, namely competencies of knowledge, attitudes, and skills. In the competence of knowledge of citizens are given an education about the nature of the sea and its influence on the life of living beings and diving training. Maumere Diver Community applies attitude competence is by becoming an example for citizens to instill a caring attitude towards the marine environment and its sustainability. While on skills competency, Maumere Diver Community collaborates with Trash Hero community in waste processing in order to increase selling value.
\end{abstract}

Copyright @ 2021 (Ludovikus Bomans Wadu, Andri Fransiskus Gultom, Maria Regina Wesa Wunu). All Right

How to Cite: Wadu, L. B., Gultom, A.F., \& Wunu, M.R.W. (2021). Penerapan Kompetensi Kewarganegaraan dalam Upaya Konservasi Ekosistem Laut Melalui Keterlibatan Maumere Diver Community. Jurnal Ilmiah Mimbar Demokrasi, 20(2), 1-11. DOI: 10.21009/jimd.v20i2.17563

This work is licensed under a Creative Commons Attribution-Share Alike 4.0 International License. Allows readers to read, download, copy, distribute, print, search, or link to the full texts of its articles and allow readers to use them for any other lawful purpose. The journal hold the copyright. 


\section{Pendahuluan}

Pendidikan Kewarganegaran menentukan mutu warga negara itu sendiri (Egin, \& Bryan, 2002). Penentuan mutu dalam konteks Pendidikan Kewarganegaraan bisa dipahami melalui lingkup pendidikan formal yakni mulai dari tingkat Sekolah Dasar sampai Perguruan Tinggi. Mutu yang dicapai berupa pemahaman teoritis tentang ideologi, kecintaan pada bangsa, dan strategi untuk melibatkan warga negara dalam bidang-bidang kehidupan. Dalam lingkup pendidikan non formal, Pendidikan Kewarganegaraan ada dalam bentuk keterlibatan dan tindakan-tindakan voluntaristik dalam keseharian bermasyarakat. Pendidikan Kewarganegaraan yang diterapkan ke dalam lingkup pendidikan non formal mampu meningkatkan pengetahuan warga negara, menumbuhkan karakter serta keterampilan warga negara agar dapat menghadapi situasi dalam kehidupan sosial (Blaskó, Costa, \& Vera-Toscano, 2019). Dengan adanya Pendidikan Kewarganegaraan mampu mencapai tujuan yakni menjadikan warga negara yang baik dan cerdas agar di dalam lingkup kehidupan bermasyarakat mampu menerapkan kegiatan-kegiatan positif yang berdampak pada perkembangan zaman yang nantinya tidak hanya menikmati hasilnya semata namun ikut terlibat dalam kegiatan-kegiatan yang dapat mengarahkan seluruh warga negara menjadi sejahtera (Kardiman, 2014).

Ada beberapa kompetensi dalam Pendidikan kewarganegaraan di antaranya kompetensi pengetahuan, watak atau sikap, dan keterampilan kewarganegaraan (Komalasari, 2011). Pengetahuan warga negara merupakan suatu potensi dasar atau pemahaman yang dimiliki oleh warga negara, kemudian sikap adalah sifat atau perilaku yang muncul akibat adanya suatu pengaruh dari dalam diri maupun lingkungannya, sedangkan keterampilan diartikan sebagai kemampuan dalam mengkoordinasikan akal budi untuk menjalankan sesuatu atau pekerjaan tersebut agar menghasilkan suatu karya yang bermanfaat (Raharjo, Armawi, \& Soerjo, 2017). Kompetensi tersebut tidak hanya didapatkan pada lingkungan pendidikan formal namun juga dapat diperoleh warga negara dalam lingkungan pendidikan non formal (Kardiman, 2014). Hal ini bertujuan agar warga negara tidak saja mendapatkan materi di sekolah tetapi juga mendapatkan contoh nyata yang terjadi di masyarakat artinya warga negara terlibat langsung dalam kegiatan tersebut sehingga masyarakat langsung beradaptasi dengan lingkungan sekitar.
Salah satu kegiatan yang mengacu pada partisipasi warga dalam memperbaiki kondisi sosial masyarakat agar dapat berdampak bagi masyarakat banyak dinamakan keterlibatan warga negara. Keterlibatan warga negara apabila sudah dibekali dengan pengetahuan, sikap, maupun keterampilan warga negara maka dapat memunculkan respon warga negara untuk mencapai suatu tujuan yang dibuat di dalam kehidupan bermasyarakat (Gusmadi, 2018). Ketika warga negara terlibat dalam suatu kegiatan yang ada di masyarakat mampu mempengaruhi warga negara yang lainnya untuk melibatkan diri dalam melaksanakan suatu kegiatan sehingga akan semakin mudah dijalankan kemudian manfaatnya juga bisa dirasakan bersama. Hal ini dapat disimpulkan bahwa penguasaan terhadap ketiga kompetensi tersebut sangat berpengaruh dalam keterlibatan warga negara itu sendiri sehingga mampu memainkan perannya sebagai warga negara yang aktif terlibat dalam segala kegiatan terkait dengan tujuan yang dibuat sehingga manfaatnya dapat dirasakan dalam jangka waktu yang panjang.

Kegiatan pembangunan tidak mutlak apabila tidak dapat dirasakan manfaatnya dalam jangka waktu yang lama sehingga akan mengurangi pemenuhan kebutuhan masyarakat dalam jangka waktu yang lama. Pembangunan Berkelanjutan atau Sustainable Development merupakan suatu kegiatan pembangunan yang dibentuk oleh masyarakat agar dapat memenuhi kebutuhan masyarakat dalam jangka waktu yang panjang. Pembangunan berkelanjutan sebagai kebijakan utama, dengan fokus pada usaha meningkatkan kapasitas warga negara di banyak bidang lingkungan dan pembangunan. Pembangunan berkelanjutan pada dasarnya merupakan bentuk refleksi diri secara kritis untuk memperoleh nilainilai yang bisa menjadi intervensi dalam bentuk tindakan nyata. Gagasan pembangunan berkelanjutan, makna yang bervariasi dan kontribusi disiplin ilmu yang berbeda. Ada yang menyebutnya development theory dan environmentalism. (Rogers, Jalal, \& Boyd, 2012).

Asal usul pembangunan berkelanjutan diinisiasi oleh Perserikatan Bangsa-Bangsa (PBB) di tahun 1984. PBB melalui kelompok independen yang terdiri dari 22 orang dari beberapa negara anggota, lalu diminta untuk mengidentifikasi strategi lingkungan jangka panjang untuk komunitas internasional. Laporan Komisi Dunia tentang Lingkungan dan Pembangunan berjudul Our Common Future (WCED, 1987) secara luas dianggap telah menjadi kunci dalam menempatkan 


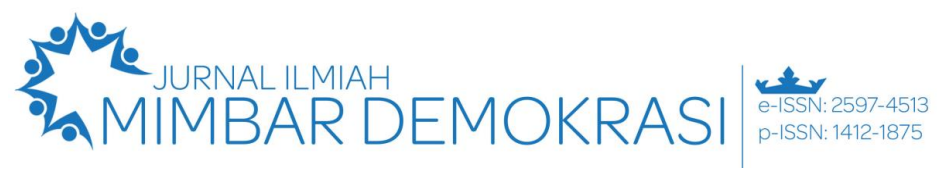

\section{Vol. 20 No. 2 Tahun 2021 | Hal. 81 - 88}

pembangunan berkelanjutan dengan kuat ke dalam arena politik pemikiran pembangunan internasional. Dalam konteks ini, istilah pembangunan berkelanjutan secara luas dimengerti sebagai pembangunan yang memenuhi kebutuhan masa kini tanpa mengorbankan kemampuan generasi mendatang untuk memenuhi kebutuhan mereka sendiri.

Pembangunan berkelanjutan bisa dijalankan maupun dioptimalkan kembali ketika ada keterlibatan warga negara dalam lingkungan masyarakat baik itu kegiatan yang mengarahkan ke dalam pembangunan ekonomi, sosial maupun perlindungan lingkungan. Selain itu dengan terjalankannya pembangunan dalam lingkungan mampu meningkatkan kesejahteraan masyarakat baik itu dalam pemenuhan kebutuhan sehari-hari maupun kenyamanan dan keamanan dalam lingkungan kehidupan masyarakat. Untuk mencapai segala tujuan tersebut maka perlu adanya peningkatan pembangunan berkelanjutan yang bersifat adil dan merata serta mengetahui keberadaan potensi-potensi alam yang dimiliki (Rahardian, 2016). Dari berbagai penjelasan di atas dapat disimpulkan bahwa yang paling berperan dalam menjalankan tujuan tersebut di atas adalah generasi muda yang mempunyai pegangan dasar Pendidikan Kewarganegaraan yang mencakup keterlibatan warga negara dan pembangunan berkelanjutan.

Penerapan Pendidikan Kewarganegaraan saat ini sudah banyak yang dilakukan dalam lingkup pendidikan formal. Penerapan Pendidikan Kewarganegaraan yang ditandai dengan bagaimana kontribusinya dalam membangun warga negara menjadi lebih baik lagi seperti Blaskó et al. (2019), Reichert \& Purta (2019), Dusi, Steinbach, \& Messetti (2012), Takkac \& Akdemir (2012). Selain berkaitan dengan Pendidikan Kewarganegaraan ada juga yang meneliti tentang keterlibatan warga negara yang di dalamnya lebih mencakup kepada pemberdayaan keterlibatan warga negara. Seperti Stefaniak, Bilewicz, \& Lewicka, (2017), Chan (2019), Hassan \& Hamari (2020), dan Chan \& Mak (2020). Ada juga yang sudah meneliti terkait dengan pembangunan berkelanjutan di antaranya masih meneliti tentang tujuan dari pembangunan berkelanjutan itu sendiri, seperti Campo, Gazzola, \& Onyango (2020), Fukuda-Parr \& Muchhala (2020), Wang et al. (2019), Jing \& Wang (2020), dan Visserenhamakers (2020).

Dari berbagai penelitian di atas, belum terdapat penelitian tentang penerapan Pendidikan Kewarganegaraan dalam lingkup pendidikan non formal atau Citizenship Education melalui Maumere Diver Community yang di dalamnya terdapat keterlibatan warga negara dan pembangunan berkelanjutan. Fokus penelitian ini untuk menjawab pertanyaan, bagaimana penerapan kompetensi kewarganegaraan dalam mengkonservasi laut melalui keterlibatan Maumere Diver Community? Pendidikan Kewarganegaraan sangatlah berkaitan erat dengan ketiga kompetensi kewarganegaraan yakni sikap, pengetahuan, dan keterampilan kewarganegaraan. Sedangkan pada keterlibatan warga negara yaitu warga negara diajak untuk terlibat secara langsung dalam setiap program kegiatan yang dijalankan. Selain itu Maumere Diver Community juga mengarahkan segala kegiatan yang dijalankan tersebut juga ke pembangunan berkelanjutan yakni dengan cara konservasi ekosistem laut.

\section{Metode}

Metode penelitian ini adalah kualitatif deskriptif dengan memberi gambaran pada satu studi kasus. Studi kasus digunakan untuk memberikan pemahaman pada sesuatu yang menarik perhatian dan mampu menangkap kompleksitas satu kasus. Metode ini berkembang dalam ilmu-ilmu sosial, termasuk dalam bidang yang berorientasi studi lingkungan, pendidikan, maupun bisnis (Johanson, 2003). Studi kasus (case study) berciri kualitatif namun sebagian lagi tidak. Misalnya, studi kasus tentang penerapan kompetensi warga negara dalam upaya konservasi laut melalui keterlibatan Maumere Diver Community lebih bercorak kualitatif daripada kuantitatif. Sebagai pendekatan, kunci penelitian studi kasus memungkinkan untuk menyelidiki suatu peristiwa yang terjadi pada individu, kelompok, dan komunitas. Penelitian studi kasus, dengan demikian bisa membantu untuk menunjukkan halhal penting yang menjadi perhatian, proses sosial masyarakat dalam keadaan konkret, pengalaman pemangku kepentingan. (Hodgetts \& Stolte, 2012). Teknik pengumpulan data menggunakan observasi, wawancara dan dokumentasi. Cara menganalisis data menggunakan reduction, display, kategori, dan tema. Untuk mengecek keabsahan data menggunakan teknik triangulasi sumber, teknik, dan waktu.

\section{Hasil dan Pembahasan}

Maumere Diver Community merupakan salah satu komunitas baru yang dibentuk pada tanggal 16 September 2018 yang lalu di Maumere, Kelurahan Waioti, Kecamatan Alok, Kabupaten Sikka, Provinsi Nusa Tenggara Timur, Indonesia. 
Yang melatarbelakangi sehingga dibentuknya komunitas ini adalah karena mereka mempunyai tingkat kepedulian yang tinggi terhadap kelestarian alam laut. Selain itu juga karena potensi alam yang dimiliki oleh masyarakat di Maumere sangat bagus sehingga sayang jika tidak dilestarikan. Pada dasarnya komunitas ini difokuskan dalam membersihkan sampah dalam program yang telah dibuat yakni Clean Up baik sampah rumah tangga maupun sampah yang dihasilkan oleh aktivitas nelayan, kapal pesiar, serta para pengunjung di sekitar pesisir pantai maupun di dalam laut yang melibatkan masyarakat dan juga bekerja sama dengan komunitas lain misalnya Trash Hero, Free Diving, Pemuda Peduli Sikka, serta komunitas yang lainnya.

Selain itu dibentuknya komunitas ini karena dilihat bahwa keadaan ekosistem laut yang berada di Maumere memiliki begitu banyak potensi. Namun karena dilihat dari tragedi tsunami pada tahun 1992 tersebut yang menyebabkan kerusakan alam sekitar laut. Sehingga dapat dilihat secara langsung terkait dengan kesadaran masyarakat yang kurang peduli terhadap kelestarian ekosistem laut yang dilihat dari jumlah potensi sampah yang dihasilkan oleh aktivitas masyarakat baik masyarakat di pesisir pantai yang berjumlah kurang lebih 50\% maupun aktivitas kapal yang melintasi disekitar pantai tersebut. Sampah yang dihasilkan oleh aktivitas masyarakat tersebut seperti sampah plastik, botol kaca, kaleng bekas, maupun kain-kain bekas.

$$
\text { Ada penerapan pendidikan }
$$

kewarganegaraan melalui Maumere Diver Community di lingkungan pendidikan non formal yang difokuskan kepada ketiga kompetensi kewarganegaraan tersebut. Pada komponen kompetensi pengetahuan yang ditemukan adalah warga negara diberikan edukasi untuk lebih mengenal alam laut beserta pengaruhnya bagi kehidupan sosial mahkluk hidup Selain itu masyarakat diberi pelatihan agar bisa menciptakan penyelam yang baik dan dapat berpartisipasi aktif dalam menjaga kebersihan di dasar laut. Yang terdapat dalam kompetensi sikap yaitu Maumere Diver Community memberikan panutan yang baik bagi semua orang untuk lebih peduli dengan lingkungan laut agar semakin terlestarikan. Sedangkan kompetensi keterampilan adalah memilah sampah-sampah yang dapat menghasilkan nilai jual yang bagus.

Bersumber dari hasil penelitian bahwa penerapan pendidikan kewarganegaraan melalui Maumere Diver Community yang dikategorikan kedalam tiga kompetensi kewarganegaraan di antaranya pengetahuan, sikap, dan keterampilan. Pengetahuan sangat dibutuhkan oleh setiap warga negara yang diperoleh dari bangku pendidikan dan mempunyai tujuan khusus yaitu agar terciptanya masyarakat yang berintelektual dan dapat mewujudkan suatu pembangunan yang berkelanjutan (Mulyoto \& Samsuri, 2017). Sikap sangat dibutuhkan agar setiap warga negara memiliki pedoman dasar dari dalam pribadinya masing-masing tentang perilaku yang sudah sama dalam internalisasi nilai yang tertuang dalam Ideologi bangsa Indonesia (Suhardiyanto \& Saputro, 2017). Selain kedua kategori di atas yang paling terpenting adalah bagaimana warga negara mengimplementasikan kedua kompetensi tersebut dalam bukti nyata yang dituangkan dalam setiap keterampilan atau potensi yang sudah menyatu dalam diri agar dapat mewujudkan tujuan yang cita-citakan oleh masyarakat, bangsa, dan negara (Suyato, Murdiono, Mulyono, \& Arpannudin, 2016).

Berdasarkan analisa data untuk meningkatkan pengetahuan warga negara maka diberikan salah satu edukasi terkait pengenalan dunia laut baik di dalam laut maupun pesisir serta dampaknya bagi kehidupan mahkluk hidup lainnya. Selain itu bekerja sama dengan Dinas Pariwisata untuk melatih masyarakat tentang teknik dasar diving yang mempunyai misi yaitu untuk menambah jumlah potensi menyelam sehingga dapat dengan mudah menganalisis pentingnya dunia laut ketika dilestarikan jika diobservasi melalui dasar laut. Karena jika dilihat dengan hasil penelitian mengatakan bahwa jumlah sampah di dasar laut semakin meningkat akibat banyaknya aktivitas masyarakat di perairan laut seperti nelayan maupun kapal-kapal pesiar lainnya yang dengan sengaja membuang sampah di dalamnya. Hal ini sangat berdampak buruk bagi kehidupan ekosistem laut.

Dalam satu wawancara, seorang narasumber, mengatakan, "keindahan alam bawah laut Maumere ini sangat kaya dan beraneka ragam. Kita punya sumber daya alam bawah laut yang luar biasa hanya perlu juga ditopang oleh sumber daya manusia yang handal untuk menjaga ekosistem bawah laut itu dengan kesadaran dan tanggung jawab." Menurutnya, komunitas penyelam (kemudian menjadi nama Maumere Diver Community) beranggotakan 20 anak muda melakukan aksi bersih pantai dan laut di sepanjang kota Maumere setiap bulannya. Selain gerakan bersih-bersih, mereka juga turun ke sekolahsekolah yang ada di kabupaten Sikka untuk mengampanyekan tentang gerakan sayang laut dengan tidak membuang sampah ke laut. Aksi 


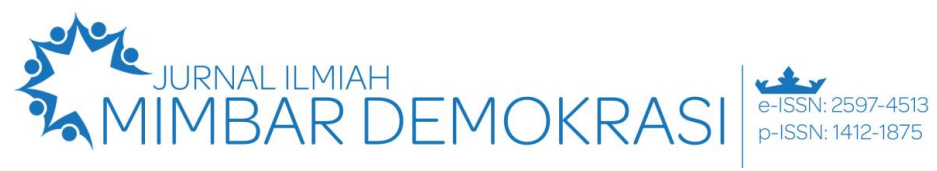

\section{Vol. 20 No. 2 Tahun 2021 | Hal. 81 - 88}

tersebut berguna untuk menjaga ekosistem laut dari berbagai kerusakan baik yang dilakukan manusia, ataupun oleh destruksi alam. Aksi yang dilakukan para anak muda itu menjadi bentuk keterlibatan warga negara dalam sustainable development yang memuat tiga kompetensi kewarganegaraan yakni pengetahuan, sikap, dan keterampilan.

Kompetensi

pengetahuan terimplementasi melalui upaya memberi kesadaran tentang pentingnya menjaga alam terutama ekosistem laut. Dimensi kognitif dilakukan dengan memberi pemahaman melalui upaya mengampanyekan ke sekolah-sekolah tentang konservasi ekosistem laut dengan membersihkan sampah. Penjelasan tentang kompetensi sikap yang ada pada Maumere Diver Community adalah dengan menjadi teladan bagi masyarakat lainnya dengan bekerja sama dengan komunitas lain untuk mengajak masyarakat untuk meningkatkan kembali sikap peduli terhadap lingkungan laut dengan mengikuti kegiatan Clean Up dalam bentuk berpartisipasi aktif dalam memungut sampah di sekitar pesisir maupun di dasar laut. Jika alam laut terlestarikan dampak yang diterima oleh masyarakat adalah manfaat-manfaat positif berkelanjutan seperti hasil laut yaitu terumbu karang semakin banyak dan berkembang biak, jika sudah berkembang maka potensi ikan yang dihasilkan juga akan semakin meningkat. Dengan berkolaborasi dengan komunitas-komunitas lain maka keterampilan masyarakat akan semakin baik misalnya dalam mengolah sampah, masyarkat diajak untuk memilih dan memilah sampah yang dapat digunakan menjadi barang jadi dan mempunyai nilai jual yang tinggi. Sebab sampah yang sering muncul adalah sampah plastik dan besi.

Penerapan Pendidikan Kewarganegaraan dengan demikian dapat mempengaruhi ketiga kompetensi kewarganegaraan yakni sikap, pengetahuan, dan keterampilan. Dengan adanya Maumere Diver Community mampu mengarahkan warga negara agar lebih aktif dalam setiap kegiatankegiatan yang dijalankan. Hal ini bertujuan agar tidak hanya sebagian warga negara saja yang mempunyai kesadaran tinggi saja melainkan seluruh warga negara agar bertanggungjawab untuk meningkatkan kesejahteraan hidup dalam lingkup bangsa dan negara (Susanto, 2014). Untuk itulah sangatlah diperlukan generasi-generasi muda yang lebih berperan aktif dalam memajukan bangsa dan negara dalam mencapai tujuan yang telah dibuat (Wulandari, Arifien, \& Suharini, 2018). $\begin{array}{ccc}\text { Selain } & \text { Penerapan Pendidikan } \\ \text { Kewarganegaraan } & \text { dalam komunitas ini juga }\end{array}$ terdapat keterlibatan warga negara di dalamnya. Tujuan yang dibuat dalam Maumere Diver Community ini adalah agar potensi alam yang terdapat di Maumere tetap dilestarikan sehingga masyarakat yang ada di dalamnya juga akan sejahtera. Selain itu dengan adanya program Clean Up yang dibuat oleh Maumere Diver Community mampu meningkatkan keterlibatan warga negara secara langsung. Keterlibatan langsung merupakan bertindak secara langsung dalam menuangkan ideide yang dilihat secara fisik dalam suatu kegiatan (Henryk, 2013).

Berdasarkan hasil penelitian untuk meningkatkan keterlibatan warga negara dalam menjalankan program Clean Up maka Maumere Diver Community mengajak masyarakat baik itu secara langsung maupun melalui postinganpostingan di media sosial. Hal ini bertujuan agar seluruh masyarakat terlibat secara langsung dalam memungut sampah di pesisir pantai maupun di dalam laut dan hasilnya masyarakat sekitar sangat antusias dalam mengikuti program Clean Up tersebut. Dapat disimpulkan bahwa dengan adanya Pendidikan Kewarganegaraan yang ada di lingkungan sosial masyarakat (Citizenship Education) dapat memperbaiki ketidaksesuaian pandangan warga negara akan pentingnya melestarikan lingkungan laut (Syahri, 2016). Dengan demikian segala kegiatan yang dibangun bersama akan berdampak baik di masa yang akan datang.

Dalam mengembangkan upaya tersebut perlu adanya kerja sama dari setiap warga negara sehingga dapat meningkatkan kesadaran masyarakat dalam melestarikan laut (Winata \& Yuliana, 2010). Hal ini dapat dapat disimpulkan bahwa meningkatnya kelestarian laut karena ada kerja sama dari berbagai pihak dalam menanggulangi kerusakan laut akibat sampah. Dari hasil penelitian yang ada di lapangan bahwa untuk melestarikan laut, Maumere Diver Community membuat suatu program Clean Up yang melibatkan masyarakat dalam membersihkan laut. Dengan demikian laut akan terhindar dari segala jenis sampah dan dapat meningkatkan kelestariannya dan tingkat kesadarannya pun semakin baik.

Selain keterlibatan warga negara yang diterapkan oleh Maumere Diver Community juga terdapat Pembangunan Berkelanjutan di dalamnya. Apabila warga negara sering terlibat dalam kegiatan-kegiatan yang ada di dalam lingkungan masyarakat dapat meningkatkan pula keterlibatan warga negara yang secara langsung untuk menciptakan pembangunan yang tujuannya 
mengarahkan ke masa depan (Abdillah, 2015). Komunitas ini membuat suatu program Clean Up yang tujuannya dapat mengarahkan ke pembangunan berkelanjutan (Wadu, Gultom, \& Pantus, 2020). Program yang telah dibuat sangat erat dengan kelestarian ekosistem laut maupun ekosistem pesisir yang terdapat di laut Maumere yang pada dasarnya memeiliki potensi yang sangat tinggi sehingga mampu diajaga dan dimanfaatkan dalam jangka waktu yang lama.

Untuk mewujudkan pembangunan berkelanjutan yang dimaksud bahwa melalui Maumere Diver Community masyarakat diajak untuk melindungi ekosistem darat maupun ekosistem laut. Melindungi ekosistem darat, Maumere Diver Community mengarahkan masyarakat untuk memungut sampah di sekitar pesisir pantai. Sedangkan melindungi ekosistem laut, masyarakat diajak untuk memungut sampah di dasar laut. Kegiatan ini dijalankan dua kali dalam seminggu yakni di minggu pertama dan minggu terakhir. Sehingga dapat disimpulkan bahwa ketika ekosistem darat maupun ekosistem laut dilindungi maka akan mendapatkan perubahan besar baik itu manfaat yang akan diperoleh sekarang maupun yang akan datang.

\section{Simpulan}

Pendidikan Kewarganegaraan diperoleh melalui lingkungan pendidikan formal dan pendidikan non formal. Penerapan pendidikan kewarganegaraan melalui Maumere Diver Community dapat dilihat secara nyata melalui tiga kompetensi kewarganegaraan yakni pengetahuan tentang pengenalan dan dampak dari ekosistem laut bagi kehidupan masyarakat serta pelatihan diving. Penerapan kompetensi sikap dengan memberikan teladan bagi warga negara dalam menanamkan sikap peduli terhadap dunia laut dengan cara membersihkan sampah yang ada di pesisir maupun di dalam laut dengan program Clean Up, yaitu mengajak warga melalui postingan di media sosial untuk membersihkan pesisir pantai maupun dalam laut dari sampah. Kompetensi keterampilan diterapkan dengan mengolah sampah dengan daur ulang menjad kerajinan-kerajinan tangan yang memiliki nilai jual yang tinggi. Keterampilan lain ada dalam bentuk keterlibatan melalui kegiatan sampah-sampah tersebut bisa didaur ulang dalam bentuk kerajinan-kerajinan tangan. Hasilnya semakin banyak masyarakat yang antusias dalam mengikuti kegiatan tersebut sehingga dapat mengurangi potensi sampah yang dihasilkan. Dengan adanya program ini, tingkat kepedulian masyarakat akan pentingnya kelestarian laut karena sangat berdampak bagi pertumbuhan biota laut, alam pesisir pantai, maupun pada kebutuhan masyarakat itu sendiri karena sumber pangan masyarakat juga berasal dari laut.

Saran untuk penelitian selanjutnya adalah agar dapat meneliti proses pengolahan sampah yang dilakukan oleh Maumere Diver Community karena komunitas ini bekerja sama dengan komunitas lain, maka sangat diharapkan untuk lebih secara mendetail meneliti tentang programprogram kerja komunitas lain yang melibatkan masyarakat untuk mendapatkan hasil penerapan Pendidikan Kewarganegaraan di komunitas tersebut.

\section{Referensi}

Abdillah, F. (Universitas P. I. (2015). Pengembangan Keterlibatan Warga Negara Melalui Penggalangan Dana Online Untuk Memupuk Tanggung Jawab Sosial Mahasiswa : Studi Grounded Theory Proyek Crowdfunding Bantu Baca di Kitabisa.com. Retrieved from http://repository.upi.edu/17879/

Blaskó, Z., Costa, P. D. da, \& Vera-Toscano, E. (2019). Non-cognitive civic outcomes: How can education contribute? European evidence from the ICCS 2016 study. International Journal of Educational Research, 98, 366-378. https://doi.org/10.1016/j.ijer.2019.07.005

Campo, A. G. Del, Gazzola, P., \& Onyango, V. (2020). The mutualism of strategic environmental assessment and sustainable development goals. Environmental Impact Assessment Review, 82(November 2019), 106383. https://doi.org/10.1016/j.eiar.2020.106383

Chan, C. (2019). Using digital storytelling to facilitate critical thinking disposition in youth civic engagement: A randomized control trial. Children and Youth Services Review, 107, 104522. https://doi.org/10.1016/j.childyouth.2019.10 4522

Chan, R. C. ., \& Mak, W. W. . (2020). Empowerment for civic engagement and wellbeing in emerging adulthood: Evidence from cross-regional and cross-lagged analyses. Social Science and Medicine, 244, 112703. https://doi.org/10.1016/j.socscimed.2019.11 2703

Dusi, P., Steinbach, M., \& Messetti, G. (2012). Citizenship Education in Multicultural Society: Teachers' Practices. Procedia - Social and Behavioral Sciences, 69, 1410-1419. https://doi.org/10.1016/j.sbspro.2012.12.080

Egin, I. F., \& Bryan, T. (2002). Citizenship studies: An introduction. Handbook on citizenship 


\section{(5)}

\section{Vol. 20 No. 2 Tahun 2021 | Hal. 81 - 88}

studies, 1-10.

Fukuda-Parr, S., \& Muchhala, B. (2020). The Southern origins of sustainable development goals: Ideas, actors, aspirations. World Development, 126(September 2015), 104706. https://doi.org/10.1016/j.worlddev.2019.104 706

Gusmadi, S. (2018). Keterlibatan Warga Negara (Civic Engagement) dalam Penguatan Karakter Peduli Lingkungan. Mawa'Trb: Jurnal Dakwah Dan Pengembangan Sosial Kemanusiaan, 9(1), 105117. https://doi.org/10.32923/maw.v9i1.718

Hassan, L., \& Hamari, J. (2020). Gameful civic engagement: A review of the literature on gamification of e-participation. Government Information Quarterly, (June 2019), 101461. https://doi.org/10.1016/j.giq.2020.101461

Henryk, S. (2013). Partisipasi masyarakat dalam pembangunan di kelurahan sungai keledang kecamatan samarinda seberang kota samarinda. Journal Ilmu Pemerintahan, 1(2), 612-625.

Hodgetts, D. J., \& Stolte, O. M. E. (2012). Case-based research in community and social pychology: Introduction to the special issue. Journal of Community \& Applied Social Psychology, 22, 379-389. doi: 10.1002/casp. 2124

Jing, Z., \& Wang, J. (2020). Sustainable development evaluation of the societyeconomy-environment in a resource-based city of China:A complex network approach. Journal of Cleaner Production, 121510. https://doi.org/10.1016/j.jclepro.2020.12151 0

Johanson, R. (2003). Case study methodology. International Conference "Methodolo-gies in Housing Research" organised by the Royal Institute of Technology in cooperation with the International Association of People-Environment Studies, Stockholm, 22-24 September 2003.

Kardiman, Y. (2014). Pendidikan Pancasila Dan Kewarganegaraan Untuk Kelompok Masyarakat. Jurnal Ilmiah Mimbar Demokrasi, 14(1), $1-13$. https://doi.org/10.1017/CBO978110741532 4.004

Komalasari, K. (2011). Kontribusi Pembelajaran Kontekstual untuk Pengembangan Kompetensi Kewarganegaraan Peserta Didik SMP di Jabar. Jurnal Sosial Dan Pembangunan, 27(1), 47-55. Retrieved from https:// ejournal.unisba.ac.id/index.php/mim $\mathrm{bar} /$ article/view/311/62

Mulyoto, G. P., \& Samsuri. (2017). Pengaruh model project citizen dengan pendekatan saintifik terhadap penguasaan kompetensi kewarganegaraan dalam pembelajaran Pendidikan Pancasila dan Kewarganegaraan. Jurnal Civics: Media Kajian Kewarganegaraan, 14(1), 105-118.

https://doi.org/10.21831/civics.v14i1.14566

Rahardian, A. H. (2016). Strategi Pembangunan Berkelanjutan. Prosiding Seminar STLAMI, III (01), 46-56. Retrieved from https://lfip.org/english/pdf/bali-

seminar/Pembangunan Berkelanjutan - Daud Silalahi.pdf

Raharjo, Armawi, A., \& Soerjo, D. (2017). Penguatan Civic Literacy Dalam Pembentukan Warga Negara Yang Baik (Good Citizen) Dan Implikasinya Terhadap Ketahanan Pribadi Warga Negara Muda (Studi Tentang Peran Pemuda HMP PPKn Demokratia pada Dusun Binaan Mutiara Ilmu di Jebres, Surakarta, Jawa Tengah. Jumal Ketahanan Nasional, 23(2), 175198. https://doi.org/10.22146/jkn.26457

Reichert, F., \& Purta, J. T. (2019). A cross-national comparison of teachers' beliefs about the aims of civic education in 12 countries: A personcentered analysis. Teaching and Teacher Education, 77 , 112-125. https://doi.org/10.1016/j.tate.2018.09.005

Rogers, P. P., Jalal, K. F., \& Boyd, J. A. (2012). An introduction to sustainable development. Earthscan, London

Stefaniak, A., Bilewicz, M., \& Lewicka, M. (2017). The merits of teaching local history: Increased place attachment enhances civic engagement and social trust. Journal of Environmental Psychology, 51, 217-225. https://doi.org/10.1016/j.jenvp.2017.03.014

Suhardiyanto, A., \& Saputro, I. H. (2017). Kontribusi Pendidikan Kewarganegaraan dalam Upaya Penguatan Nilai-Nilai Kebangsaan di Era Globalisasi. Prosiding Semonar Nasional PKn-Unnes, 1(1), 9-14. Retrieved from https://journal.uny.ac.id/index.php/civics/ar ticle/view/14566/9490

Susanto, A. (2014). Pengaruh Pendidikan Kewarganegaraan Sebagai Wahana Pengembangan Kompetensi Kewarganegaraan (Civic Competences) Terhadap Kehidupan Demokrasi Siswa Kelas IX SMPN 1 Bungkal Tahun Pelajaran 2013/2014. Ilmu Pendidikan, 203.

Suyato, Murdiono, M., Mulyono, B., \& Arpannudin, I. (2016). Upaya Pembentukan Warga Negara Yang Baik Dan Tantangan Yang 
Dihadapi Oleh Para Guru PKn Peserta SM3T 2015. Jurnal Civics, 13(2), 137-150. Retrieved from

https://journal.uny.ac.id/index.php/civics/ar ticle/view/12737/pdf

Syahri, M. (2016). Bentuk - Bentuk Partisipasi Warga Negara Dalam Pelestarian Lingkungan Hidup Berdasarkan Konsep Green Moral Di Kabupaten Blitar. Jurnal Penelitian Pendidikan, 13(2). Retrieved from https://ejournal.upi.edu/index.php/JER/arti cle/view/3423/2415

Takkac, M., \& Akdemir, A. S. (2012). Training Future Members of the World with an Understanding of Global Citizenship. Procedia Social and Behavioral Sciences, 47, 881-885. https://doi.org/10.1016/j.sbspro.2012.06.751

Visseren-hamakers, I. J. (2020). The 18 th Sustainable Development Goal. Earth System Governance, $\quad$ (xxxx), 100047. https://doi.org/10.1016/j.esg.2020.100047

Wadu, L.B, Gultom, A.F., Pantus, F. (2020). Penyediaan Air Bersih Dan Sanitasi : Bentuk Keterlibatan Masyarakat Dalam Pembangunan Berkelanjutan. Jurnal Pendidikan Kewarganegaraan, $\quad$ 10(2), 80-88. http://dx.doi.org/10.20527/kewarganegaraan .$v 10 \mathrm{i} 2.9318$

Wang, Y., Lu, Y., He, G., Wang, C., Yuan, J., \& Cao, X. (2019). Spatial variability of sustainable development goals in China: A provincial level evaluation. Environmental Development, 100483. https://doi.org/10.1016/j.envdev.2019.10048 3

WCED (World Commission on Environment and Development) (1987) Our Common Future, Oxford University Press, Oxford

Winata, A., \& Yuliana, E. (2010). Peran Masyarakat Pesisir Dalam Penerapan Strategi Konservasi Sumberdaya Laut (Kasus Di Kelurahan Palabuhanratu , Kecamatan Palabuhanratu , Kabupaten Sukabumi ). Jurnal Matematika, Sains, Dan Teknologi, 11(2), 122132. Retrieved from http://www.jurnal.ut.ac.id/index.php/jmst/ar ticle/view/573/557

Wulandari, A. D., Arifien, M., \& Suharini, E. (2018). Perilaku Peduli Lingkungan Masyarakat dalam Pengelolaan Desa Wisata Kandri Kecamatan Gunung Pati. Edu Geography, 6(3), 170-176. Retrieved from http://journal.unnes.ac.id/sju/index.php/edu geo $\% 25$ 